\title{
MODIFIED POLYMER MATERIALS FOR USE IN SELECTED PERSONAL PROTECTIVE EQUIPMENT PRODUCTS
}

\author{
Emilia Irzmańska, Agnieszka Brochocka
}

Central Institute for Labor Protection - National Research Institute

Department of Personal Protective Equipment (Warsaw, Poland)

mail to: emirz@ciop.lodz.pl

fax: (+48 042) $678-19-15$

\begin{abstract}
:
The paper discusses the methods of modification of melt-blown polymer materials by the addition of a bactericidal agent or superabsorbent directly to the fibre-forming area during the melt-blown production process. It also presents tests of textile composites designed for use in selected types of personal protective equipment worn in the workplace. One example of the application of textile composites is the protective footwear insole. The insole composites contain specially developed variants of melt-blown nonwovens made from PP, PC, and PA fibres. Microbiological, hygienic, and mechanical tests have shown that the optimum insoles for all-rubber protective footwear are those made of bioactive composites containing a PC melt-blown nonwoven. Another example of composite application is the air-purifying half mask. Filter composites contain polymer nonwovens with the addition of different quantities of a superabsorbent. They have been tested for particle penetration, airflow resistance, and moisture sorption.
\end{abstract}

\section{Keywords:}

superabsorbents; melt-blown polymer materials;personal protective equipment

\section{Introduction}

The European Textile market poses new challenges to the polymer nonwoven sector, necessitating the development of new technologies, products with specialised structure and unconventional properties, and new applications. The considerable interest in the manufacture and use of nonwovens has been confirmed by Polish and European research projects aimed at improving the safety and comfort of workers using personal protective equipment (PPE). A variety of textile composites have been developed by designers and manufacturers to ensure that the PPE products used both in the workplace and in other settings are sufficiently comfortable. Such composites have been used in contoured footwear insoles and air-purifying half masks providing protection to the human respiratory system, featuring a specialised structure, unconventional properties, and new applications. Taking into consideration the advantages of nonwoven materials, it should be stressed that the demand for specialised nonwoven product is on the increase. Thus, from the scientific point of view, further research is necessary into new polymers, modifiers and surface modification technologies. Depending on the quantitative and qualitative composition of the material, morphological structure, modifiers, hydrophilicity or hydrophobicity, and structure modification techniques, polymer nonwovens have found many applications in a variety of industrial sectors. For instance, numerous respiratory protective devices contain multilayer nonwovens produced by different methods. Considerable research is also being conducted in the field of surface modification by means of low-temperature plasma, nanostructures and biodegradable polymers $[1,27,30,37,38$, 40]

A popular method of modification of polymer materials is the electrostatic activation involving low-temperature atmosphericpressure plasma, and in particular corona discharge. Such techniques have been explored in several research works on the theory and mechanisms of corona charging of polymer materials $[5,8,32,36,41]$. Those works studied the relationship between the charge accumulation capacity and the type of direct or alternating current supplied to the activating device. Furthermore, the corona discharge process was optimised in terms of the type of charge used, voltage supplied to the discharge electrode, type of electrode, distance between the polymer material and the electrode, modification time and others [3, 31, 42]. The patent literature offers many construction solutions both as regards electrodes and activating devices $[10,28,35,39]$. Moreover, studies have been conducted on the modification of polymer textile materials using either atmospheric-pressure corona discharge or low-pressure plasma produced in plasma reactors [1, 2, 3, 38]. The results of those works show that further research should be undertaken to improve the durability of plasma modification effects.

Yet another method of functionalisation of polymer materials involves the incorporation of modifiers (additives) in the fibre structure. Patent claim [26] describes a two-step method of producing a PP composite from regranulated polymer with modifier with the addition of $2 \%$ microcrystalline cellulose or $3 \%$ microbiological chitosan. Considerable research effort 
has been undertaken to obtain nonwovens with good filtration and sorption properties using powdered activated carbon incorporated into a nonwoven by means of compressed air [7] or by adding it to the polymer stream. Other papers $[2,20]$ report the modification of melt-blown nonwovens with a biocidal agent with a view to removing pathogenic microorganisms from the air. The fibres were made of a polymer which contained antibioaerosol particles. Their efficiency was proven in biological tests on E. coli and S. aureus.

Microbiological research has also shown that bioactive filter nonwovens are useful in the construction of respiratory protective devices (novel bioactive air-purifying half masks). It has been reported [11] that modern disposable personal hygiene items and healthcare articles should exhibit excellent absorbability in order to offer good comfort of use. However, it can be easily predicted that improvement in one parameter may lead to deterioration in other functions of a nonwoven composite containing a superabsorbent polymer. It should also be remembered that the manufacturing technology of such nonwovens is uneconomical. The costs of highly specialised materials must be reduced by increasing production efficiency and effectiveness, both for individual components (such as adhesives, superabsorbents, functional synthetic fibres, cellulose pulp) and for the entire technological process. An alternative to this technology is offered by the production of filter nonwovens directly from a polymer stream, using the meltblown technology. Due to the specific properties of nonwoven fibres, and especially their small diameter, these materials exhibit superior filtration, absorption, and thermal insulation parameters.

The insole materials used today in protective footwear under demanding work conditions are hygroscopic products that retain high levels of moisture in their structure, which affects their hygienic properties $[17,29]$. This also hinders the safety of such protective equipment (by increasing the risk of fungal infections of the feet) and shortens the viable time of their use. An appropriate microclimate inside protective footwear may be obtained by improving the construction of insole composites. Previous research and design works mostly dealt with insole composites for casual footwear. For instance, paper [18] reports the development of two-ply composite insoles that promote unfavorable growth conditions for fungi and bacteria. The patent literature proposes many insole construction types for improvement of the comfort of use $[6,9]$.

In the case of air-purifying half masks, the most widespread cause of discomfort is skin irritation arising in the area where the half mask presses against the skin (cheeks, nose, chin). This in turn may make the workers reluctant to wear the masks, despite their high protective properties. This phenomenon is particularly important in the case of high-performance half masks, as they are typically deployed under adverse work conditions. At the same time, it should be stressed that elevated temperature and humidity inside protective equipment is conducive to the growth of pathogenic microorganisms. Under such circumstances, it is important to ensure effective heat and moisture transport away to the environment, and to impart biocidal properties to the products.
Currently, in the European market there is no multifunctional melt-blown nonwoven material that would exhibit both increased mechanical strength and high levels of moisture transport and microbial inhibition in nonpermeable protective footwear. Similarly, there is no filter material with high filtration capacity (low penetration indicator) at low airflow resistance that would also be characterised by sufficient mechanical stability and sorption. Aim of the study was presented tests of textile composites designed for use in selected types of personal protective equipment worn in the workplace and discussed methods of modification of melt-blown polymer materials by the addition of a bactericidal agent or superabsorbent directly to the fibre-forming area during the melt-blown production process.

\section{Experimental}

Melt-blown technology was chosen due to the fact that the structure of nonwovens can be effectively adjusted in terms of nonwoven porosity and area density. Another advantage is that the manufacturing apparatus is smaller than that used in other methods of nonwoven production. It should be noted that melt-blown technology is very flexible and easily yields itself to different modifications. Despite the fact that this technology requires high energy input due to the high process temperature and considerable use of hot air, it is nevertheless preferable for environmental reasons as a so-called 'dry technology'.

The particularly innovative aspects of the presented research involve the use of polymer materials (instead of wool felts) for protective footwear insoles and the direct addition of modifiers during the melt-blown production process with a view to obtaining multifunctional polymer materials.

\section{Polymers and modifiers}

The nonwovens were produced from polymers commonly used in melt-blown technology: Moplen HP 540J crystalline polypropylene (PP) beads (Lyondell Basell Orlen, Polska), LEXAN $144 \mathrm{R}$ amorphous polycarbonate (PC) beads (General Electric Company, USA), and AQUAMID 6 polyamide beads (Aquafil Engineering Plastics S.P.A., Italy). These materials exhibit some valuable properties such as considerable thermal resistance, resistance to sterilisation conditions, shape stability, good electrical insulation properties, biological inertness and easy recycling. Table 1 presents the characteristics of the polymers used.

With a view to obtaining a multifunctional melt-blown nonwoven with improved mechanical properties, moisture transport, and microbial growth inhibition to be used in nonpermeable protective footwear, we applied a bioactive modifier, that is, commercially available magnesium monoperoxyphthalate. It was added during the process of fibre formation in an amount of $140 \mathrm{~g} / \mathrm{m}^{2}$ in the manner described in previous publications [20].

In order to produce a highly efficient filter material exhibiting low airflow resistance, sufficient mechanical stability, and good moisture sorption capacity to be used in air-purifying 
Table 1. Polymers used in the studied nonwovens

\begin{tabular}{|c|c|c|c|c|}
\hline Type of polymers & Symbols & Trade name, supplier & Density $\mathbf{g} / \mathbf{c m}^{\mathbf{3}}$ & Melt index $\mathbf{M L I}$ in $\mathbf{g} / \mathbf{1 0} \mathbf{~ m i n}$ \\
\hline $\begin{array}{c}\text { MOPLEN HP 456 J } \\
\text { polypropylene }\end{array}$ & PP & Lyondell Basell & - & 3.4 \\
\hline AQUAMID 6 polyamide & PA & $\begin{array}{c}\text { Aquafil Engineering } \\
\text { Plastics S.P.A. }\end{array}$ & $1.13-1.14$ & - \\
\hline $\begin{array}{c}\text { LEXAN 144 R } \\
\text { polycarbonate }\end{array}$ & PC & $\begin{array}{c}\text { General Electric } \\
\text { Company }\end{array}$ & 1.2 & 15.4 \\
\hline
\end{tabular}

half masks, we applied a modifier in the form of EK-X EN52 polymeric absorbent with an average grain size of approx. $250 \mu \mathrm{m}$ (coarse), as well as a superabsorbent ground with a ball mill, with an average grain size of approx. $30 \mu \mathrm{m}$, which was added to the polymer in the amount of $2.5 \mathrm{~g} / 0.8 \mathrm{~m}^{2}$ of nonwoven (approx. 3\% vol.) and $5.0 \mathrm{~g} / 0.8 \mathrm{~m}^{2}$ of nonwoven (approx. $7 \%$ vol.)

\section{Processing procedure}

Technological work was conducted using an experimental stand for the production of electret melt-blown nonwovens, which is specified in detail in paper [33]. Predried PP, PC or PA granules were transferred from the hopper to the extruder barrel (3). The polymer melt was adjusted to the desired viscosity prior to drawing from the spinning head (2). Compressed air passed from the air flow controller to the air heater (1), in which it was dried and heated up to an appropriate temperature. Then, the air flow was directed to the spinning head (2), where it hit the polymer streams exiting the nozzle, fracturing them into elementary fibres of varying thickness and length. The experimental stand had control points for adjusting technological parameters. A scheme of the stand is presented in Figure 1.

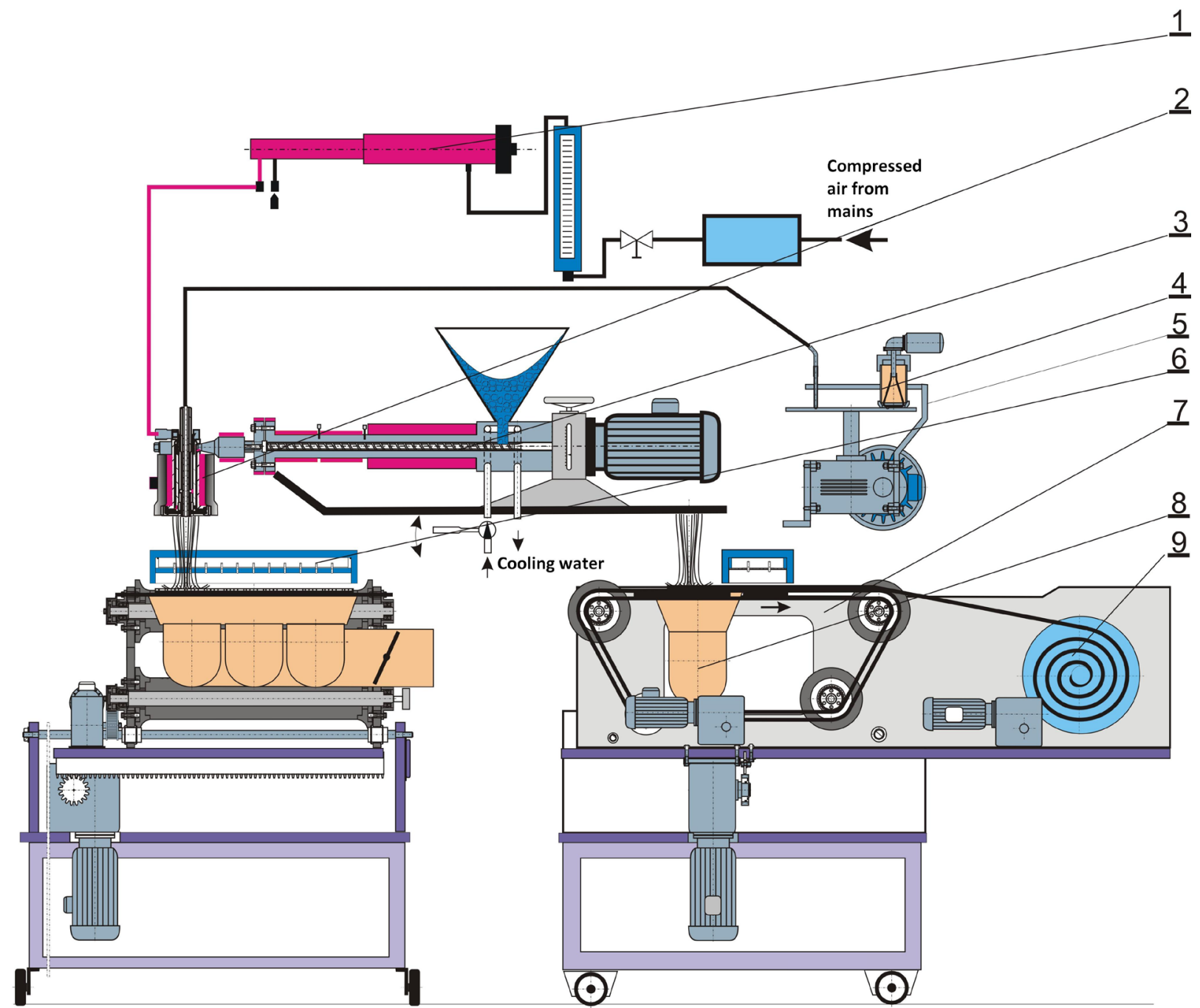

Figure 1. Scheme of technological set-up for the production of melt-blown nonwovens with modifiers: 1 - air heater, $2-$ spinning head, $3-$ extruder, 4 - modifier, 5 - modifier dispenser, 6 - activating device, 7 - collector, 8 - air suction unit, 9 - winder. 
The developed spinning head made it possible to produce fibres from any type of thermoplastic polymer and to easily connect devices injecting different modifiers. During the technological process, it was important for the polymer melt exiting the extruder to have constant parameters (mass and temperature). The optimum polymer melt viscosity for thin fibre production was achieved by means of the appropriate design of the spinning head, where final heating of the polymer melt took place. The developed spinning head design, shown in Figure 2 [33].

The modifier (4) was fed by a connecting tube (5) from the rotary dispenser to the compressed air injector. The resulting air/modifier aerosol was introduced directly into the stream of semiliquid polymer. In the case of filter materials, the fibre/ modifier mixture was additionally activated electrostatically by corona discharges (a potential difference was generated between the discharge electrode and the counter electrode). The fibre/modifier mixture was deposited on the collector (7), forming a compact nonwoven material (9). The greatest advantage of the presented technological solution is the possibility to add modifiers directly into the stream of melted polymer at the stage of elementary fibre formation. Thanks to this, modifier particles become firmly bonded to the fibres. The obtained polymer materials were applied in selected types of PPE, that is, in protective footwear (insoles) and in air-purifying half masks (filter nonwoven). The obtained variants of biocidal nonwovens for insoles and filtering sorption nonwovens are characterised in Tables 2 and 3, respectively.

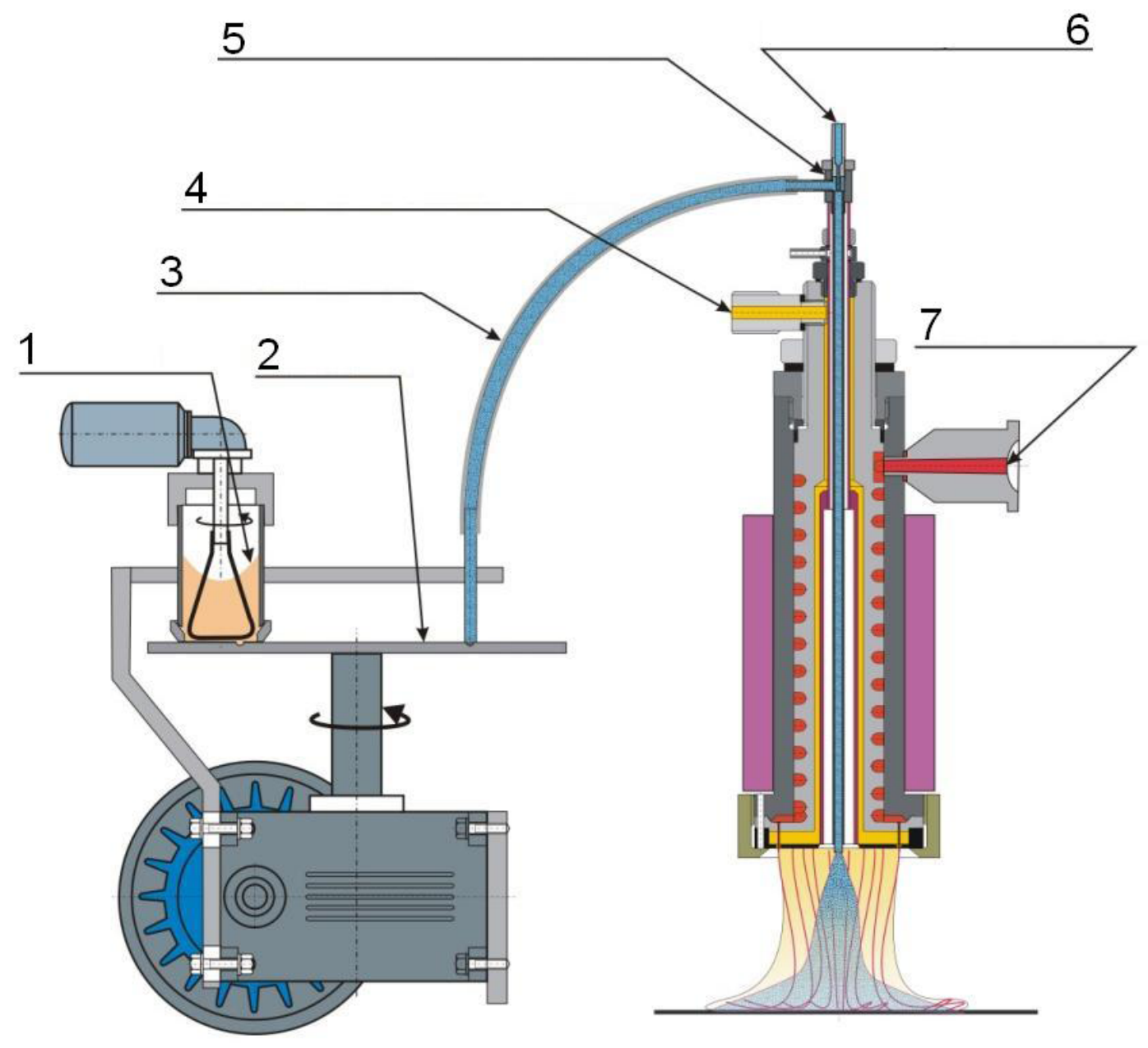

Figure 2. The spinning head and the modifier dispensing assembly: 1 - modifier, 2 - dispenser, 3 - connecting tube, 4 - hot air for blowing polymer, 5 - assembly for injecting modifier into fibre stream, 6 - compressed air generating vacuum, 7 - polymer melt from extruder

Table 2. Characteristics of biocidal melt-blown nonwovens for use in protective footwear

\begin{tabular}{|c|c|c|c|}
\hline Type of biocidal nonwoven & $\begin{array}{c}\text { Mean surface density, } \\
\mathbf{g} / \mathbf{m}^{\mathbf{2}}\end{array}$ & $\begin{array}{c}\text { Mean fibre thickness, } \\
\mathbf{n m}\end{array}$ & $\begin{array}{c}\text { Mean nonwoven thickness, } \\
\mathbf{m m}\end{array}$ \\
\hline PA nonwoven & 430 & 3177 & 3.91 \\
\hline PP nonwoven & 371 & 8393 & 3.53 \\
\hline PC nonwoven & 314 & 3006 & 3.68 \\
\hline
\end{tabular}


Table 3. Characteristics of filter-sorption melt-blown nonwovens for use in air-purifying half masks

\begin{tabular}{|c|c|c|c|c|c|}
\hline No. & Type of filter nonwoven & $\begin{array}{l}\text { Mean surface density, } \\
\mathrm{g} / \mathrm{m}^{2}\end{array}$ & $\begin{array}{c}\text { Mean fibre } \\
\text { thickness, } \\
\mu \mathrm{m}\end{array}$ & $\begin{array}{c}\text { Mean nonwoven } \\
\text { thickness, } \\
\text { mm }\end{array}$ & $\begin{array}{l}\text { Mean pore } \\
\text { area, } \\
\mathrm{m}^{2} / \mathrm{g}\end{array}$ \\
\hline 1 & PP nonwoven & 83.26 & 2.01 & 2.0487 & 2.005 \\
\hline 2 & $\begin{array}{l}\text { Corona-charged (Q) } \\
\text { PP nonwoven }\end{array}$ & 87.06 & 1.97 & 2.2081 & - \\
\hline 3 & $\begin{array}{l}\text { PP nonwoven with } 2.5 \mathrm{~g} \\
\text { of coarse superabsorbent } \\
\text { (SAP) }\end{array}$ & 95.28 & 1.54 & 2.4047 & 1.963 \\
\hline 4 & $\begin{array}{c}\text { Corona-charged PP } \\
\text { nonwoven with } 2.5 \mathrm{~g} \text { of } \\
\text { coarse SAP }\end{array}$ & 102.49 & 1.50 & 2.2892 & - \\
\hline 5 & $\begin{array}{c}\text { PP nonwoven with } 2.5 \mathrm{~g} \\
\text { of fine SAP }\end{array}$ & 102.06 & 1.01 & 2.3516 & 1.626 \\
\hline 6 & $\begin{array}{l}\text { Corona-charged PP } \\
\text { nonwoven with } 2.5 \mathrm{~g} \text { of } \\
\text { fine SAP }\end{array}$ & 99.53 & 0.99 & 2.4212 & - \\
\hline 7 & $\begin{array}{c}\text { PP nonwoven with } 5.0 \mathrm{~g} \\
\text { of fine SAP }\end{array}$ & 108.73 & 1.50 & 2.3638 & 0.723 \\
\hline 8 & $\begin{array}{c}\text { Corona-charged PP } \\
\text { nonwoven with } 5.0 \mathrm{~g} \text { of } \\
\text { fine SAP }\end{array}$ & 110.53 & 1.37 & 2.3364 & - \\
\hline
\end{tabular}

Due to the fact that footwear materials should exhibit high mechanical strength, a new technology for binding composite layers was developed (which is the subject of a patent claim by the authors) [22]. A nonadhesive binding method was used with an ultrasound applied by means of a universal vertical spot welder that performed the working motion similar to that of a pneumatic press. The spot welder was equipped with welding sonotrodes of special design and was fully adjustable to obtain optimum process parameters. During the welding process, the device was set to exert a constant welding pressure (controlled by the air pressure in the actuator) and a constant sonotrode vibration frequency (controlled by the vibration generator). The variable parameter was welding time, which depended on the type of welded materials. The composites were welded using the following optimised parameters: frequency of $45 \mathrm{MHz}$, pressure of 5 bar, and welding time of $12 \mathrm{~s}$ for PC fibres, $7 \mathrm{~s}$ for PP fibres and $10 \mathrm{~s}$ for PA fibres. Welding time was different due to different types of polymers used and their reactions to the load and the temperature. Welding points of $5 \mathrm{~mm}$ diameter were spaced every $40 \mathrm{~mm}$ across the surface of the composites.

Six variants of bioactive composites for protective footwear insoles were obtained. They are characterised in Table 4. They were previously described in greater detail by the authors in paper [20].

\section{Methodology}

Evaluation of insole quality involved mechanical, hygienic and microbiological testing [19]. As a result, the materials produced were subjected to laboratory tests and measurements for the parameters presented in Table 5.

Table 4. Obtained variants of bioactive insole composites

\begin{tabular}{|c|c|c|c|}
\hline \multirow{2}{*}{ Variant } & \multicolumn{3}{|c|}{ Structure of bioactive insole composites } \\
\cline { 2 - 4 } & Bottom layer & Middle layer & Top layer \\
\hline $\mathbf{1}$ & Reinforcing PP nonwoven & PP nonwoven with a biocidal agent & Lyocell/polyester fabric \\
\hline $\mathbf{2}$ & Reinforcing PP nonwoven & PP nonwoven with a biocidal agent & Lyocell/polypropylene fabric \\
\hline $\mathbf{3}$ & Reinforcing PP nonwoven & PC nonwoven with a biocidal agent & Lyocell/polyester fabric \\
\hline $\mathbf{4}$ & Reinforcing PP nonwoven & PC nonwoven with a biocidal agent & Lyocell/polypropylene fabric \\
\hline $\mathbf{5}$ & Reinforcing PP nonwoven & PA nonwoven with a biocidal agent & Lyocell/polyester fabric \\
\hline $\mathbf{6}$ & Reinforcing PP nonwoven & PA nonwoven with a biocidal agent & Lyocell/polypropylene fabric \\
\hline
\end{tabular}


Table 5. Properties measured in study with appropriate standards

\begin{tabular}{|c|c|c|}
\hline & Parameter & Standard \\
\hline \multirow{4}{*}{$\begin{array}{l}\text { Mechanical } \\
\text { properties }\end{array}$} & Thickness & PN-EN ISO 5084:1999 [25] \\
\hline & Abrasion resistance & PN-EN ISO 20345:2007 [23] \\
\hline & Tear resistance & PN-EN ISO 20345:2007 [23] \\
\hline & Bond strength for layers & PN-EN 1392:2007 [14] \\
\hline \multirow{5}{*}{ Hygienic properties } & $\mathrm{pH}$ of aqueous extracts, & PN-EN ISO 20345:2007 [23] \\
\hline & Water vapor permeability, & PN-EN ISO 20345:2007 [23] \\
\hline & Water vapor absorption & PN-EN ISO 20345:2007 [23] \\
\hline & Water absorption and desorption & PN-EN ISO 20345:2007 [23] \\
\hline & Thermal resistance & PN-EN 31092:1998 [34] \\
\hline \multirow{3}{*}{$\begin{array}{l}\text { Microbiological } \\
\text { resistance }\end{array}$} & $\begin{array}{l}\text { Aspergillus fumigatus and Trichophyton } \\
\text { mentagrophytes }\end{array}$ & PN-EN 14119:2005 [15] \\
\hline & $\begin{array}{c}\text { Staphylococcus aureus, Escherichia coli, and } \\
\text { Candida albicans }\end{array}$ & $\begin{array}{c}\text { PN-EN ISO 20645:2006 [24] and PN-EN } \\
\text { 14119:2005 [15] }\end{array}$ \\
\hline & Solid aerosol penetration & $\begin{array}{c}\text { EN 149:2001+A1:2009 [16], EN 13274-7:2008 } \\
\text { [13], and EN 13274-3:2001 [12] }\end{array}$ \\
\hline \multirow{2}{*}{$\begin{array}{l}\text { Protective } \\
\text { properties }\end{array}$} & Air flow resistance & $\begin{array}{c}\text { EN 149:2001+A1:2009 [16], EN 13274-7:2008 } \\
\text { [13], and EN 13274-3:2001 [12] }\end{array}$ \\
\hline & Moisture sorption & EN 149:2001+A1:2009 [16] \\
\hline
\end{tabular}

\section{Results and discussion}

Evaluation of the protective and functional properties of bioactive polymer materials for protective footwear insoles

Mean values of mechanical and hygienic parameters for the designed variants of bioactive insole composites are presented in Table 6. The results of microbiological resistance tests involving a number of microorganisms for the various designed variants of bioactive composites are given in Tables 7 to 9 .

Results of Aspergillus fumigatusand and Trichophyton mentagrophytes microbiological tests for the various variants of bioactive insole composites were 0 for all samples, what indicate on high microbiological resistance against this bacteria.

The designed insole composites for use in protective footwear exhibit good mechanical and hygienic properties and inhibit the growth of selected bacteria and fungi found in the footwear environment. The growth of microorganisms is directly determined by the microclimate in the enclosed space inside footwear, and in particular by humidity and temperature [19]. Relative humidity inside protective footwear ranges from $96 \%$ to $100 \%$, which increases the development of sweatdecomposing bacteria [21]. Analysing the microbiological contamination of footwear, one should always consider the presence of pathogenic bacteria and fungi. Colonisation of the inner area of footwear by yeast-like fungi and dermatophytes constitutes a separate microbiological problem related to fungal infections of the feet. From the point of view of footwear hygiene, of importance are also parasitic mould fungi, which often colonise moist interdigital spaces. The growth of those fungi is similar to that of bacteria - it is stimulated by increased perspiration, primarily due to wearing unhygienic footwear that is impermeable to air and water vapor. Thus, the hygienic properties of footwear may be modified by means of materials exhibiting high water vapor permeability and absorption, as well as enhanced microbiological resistance.

The test results show that the best properties are offered by the composite variant consisting of the polycarbonate nonwoven with a bioactive agent, containing a two-ply Lyocell/ polyester fabric. This variant exhibits the best mechanical and hygienic qualities among the examined options. This is directly attributable to the superior sorption and mechanical properties of PC fibres as compared with PP and PA fibres. Additional tests were conducted to evaluate the bond strength of ultrasound welds and the effect of the antimicrobial modifier on the growth of microorganisms inside footwear. The studied composites were characterised by high bond strength of layers, with the highest levels found for the variant containing a reinforcing polypropylene nonwoven (external layer), a polycarbonate nonwoven with a bioactive agent (middle layer) and a two-ply woven fabric made of cellulose fibres (Lyocell) and polyester fibres (variant III). The lowest bond strength was found for the variant containing a reinforcing PP nonwoven, a polyamide nonwoven with a biocidal agent, and a two-ply Lyocell/PP woven fabric (variant VI).

As far as antibacterial effects against Staphylococcus aureus and Escherichia coli are concerned, the largest inhibition zones were found for all the designed composite variants. In terms of antifungal evaluation, tests were conducted for Aspergillus fumigatus and Trichophyton mentagrophytes. The results 
Table 6. Mean strength and hygienic parameters of designed variants of bioactive insole materials

\begin{tabular}{|c|c|c|c|c|c|c|c|c|}
\hline \multirow{2}{*}{ 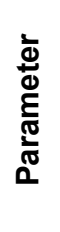 } & \multicolumn{3}{|c|}{ Mechanical parameters } & \multicolumn{5}{|c|}{ Hygienic parameters } \\
\hline & Thickness & $\begin{array}{c}\text { Longitudinal/ } \\
\text { transverse } \\
\text { tear } \\
\text { resistance }\end{array}$ & $\begin{array}{l}\text { Abrasion } \\
\text { resistance }\end{array}$ & $\begin{array}{c}\text { pH of } \\
\text { aqueous } \\
\text { extract }\end{array}$ & $\begin{array}{l}\text { Water vapor } \\
\text { permeability }\end{array}$ & $\begin{array}{l}\text { Water } \\
\text { vapor } \\
\text { rate }\end{array}$ & $\begin{array}{c}\text { Water } \\
\text { absorption }\end{array}$ & $\begin{array}{c}\text { Water } \\
\text { desorption }\end{array}$ \\
\hline $\begin{array}{l}\frac{0}{\frac{\pi}{7}} \\
\frac{\pi}{0} \\
\frac{C}{\pi} \\
\text { के }\end{array}$ & $\begin{array}{c}\text { PN-EN ISO } \\
5084: 1999 \\
{[25]}\end{array}$ & \multicolumn{2}{|c|}{ PN-EN ISO 20345:2007 [23] } & \multicolumn{5}{|c|}{ PN-EN ISO 20345:2007 [23] } \\
\hline 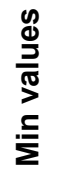 & $\min 3[\mathrm{~mm}]$ & $\begin{array}{c}\min 0.4[\mathrm{~N} / \\
\mathrm{mm}]\end{array}$ & $\begin{array}{l}\text { Number of } \\
\text { cycles until } \\
\text { sample } \\
\text { damage }\end{array}$ & $\mathrm{pH}>3.2$ & $\begin{array}{c}\min 2.0[\mathrm{mg} / \\
\left.\left(\mathrm{cm}^{2} \mathrm{~h}\right)\right]\end{array}$ & $\begin{array}{l}\min 20.0 \\
{\left[\mathrm{mg} / \mathrm{cm}^{2}\right]}\end{array}$ & $\begin{array}{l}\min 70 \\
\mathrm{mg} / \mathrm{cm}^{2}\end{array}$ & $\min 80 \%$ \\
\hline 1 & 5 & $0.3 / 0.5^{*}$ & \multirow{6}{*}{$\begin{array}{c}\text { Dry rubbing: } \\
25600 \\
\text { Wet rubbing: } \\
12800\end{array}$} & 4.5 & 11.8 & 95.2 & 230 & 108 \\
\hline 2 & 5 & $0.2 / 0.2$ & & 4.3 & 11.7 & 94.4 & 215 & 106 \\
\hline 3 & 5 & $0.2 / 0.1$ & & 4.2 & 12.8 & 103.2 & 207 & 105 \\
\hline 4 & 6 & $0.1 / 0.2$ & & 4.3 & 12.5 & 100.9 & 223 & 107 \\
\hline 5 & 6 & $0.2 / 0.2$ & & 4.3 & 11.3 & 92.1 & 220 & 106 \\
\hline 6 & 6 & $0.1 / 0.0$ & & 4.4 & 10.9 & 89.6 & 241 & 106 \\
\hline
\end{tabular}

Table 7. Results of Staphylococcus aureus microbiological tests for the various variants of bioactive insole composites

\begin{tabular}{|c|c|c|c|c|c|}
\hline $\begin{array}{l}\text { Sample } \\
\text { no. }\end{array}$ & Side of sample & $\begin{array}{l}\text { Inhibition zone } \\
\text { [mm] }\end{array}$ & $\begin{array}{l}\text { Growth on } \\
\text { agar under } \\
\text { sample }\end{array}$ & $\begin{array}{l}\text { Growth on } \\
\text { sample side } \\
\text { facing agar }\end{array}$ & Evaluation \\
\hline \multirow{2}{*}{1} & $\mathrm{I}$ & 7 & None & None & \multirow{2}{*}{ Effective } \\
\hline & II & 7 & None & None & \\
\hline \multirow{2}{*}{2} & I (fabric facing growth medium) & 12 & None & None & \multirow{2}{*}{ Effective } \\
\hline & II & 6 & None & None & \\
\hline \multirow{2}{*}{3} & $\mathrm{I}$ & 10 & None & None & \multirow{2}{*}{ Effective } \\
\hline & II & 10 & None & None & \\
\hline \multirow{2}{*}{4} & I (fabric facing growth medium) & 17 & None & None & \multirow{2}{*}{ Effective } \\
\hline & II & 10 & None & None & \\
\hline \multirow{2}{*}{5} & I (fabric facing growth medium) & 13 & None & None & \multirow{2}{*}{ Effective } \\
\hline & II & 7 & None & None & \\
\hline 6 & I (fabric facing growth medium) & 17 & None & None & Effective \\
\hline
\end{tabular}

showed that all variants were characterised by very high antifungal activity against Trichophyton mentagrophytes (grade 0 , meaning the absence of any fungal growth detectable under a magnification of $50 \times$ under a microscope).

Evaluation of the filtering and functional properties of sorption polymer materials for air-purifying half-masks

According to the literature data, the application of corona discharge during melt-blown fibre formation considerably improves the effectiveness of filtration of contaminating particles from the air flow. It has been reported that electrostatic activation led to a tenfold improvement in the protective parameters of filtering materials as compared to those not having an electrostatic charge [3]. In another study, the aerosol filtration effectiveness of all examined types of nonwovens increased by $80 \%$ at unchanged airflow resistance levels. [27]

In the present study, in order to determine the effects of the SAP contained in the filter nonwovens on their protective and functional properties, sodium chloride aerosol penetration and air flow resistance were studied under predetermined microclimate conditions (relative humidity and temperature of air). The test results showing the decrease in the penetration 
Table 8. Results of Escherichia coli microbiological tests for the various variants of bioactive insole composites

\begin{tabular}{|c|c|c|c|c|c|}
\hline $\begin{array}{c}\text { Sample } \\
\text { no. }\end{array}$ & Side of sample & $\begin{array}{l}\text { Inhibition zone } \\
{[\mathrm{mm}]}\end{array}$ & $\begin{array}{l}\text { Growth on } \\
\text { agar under } \\
\text { sample }\end{array}$ & $\begin{array}{l}\text { Growth on } \\
\text { sample side } \\
\text { facing agar }\end{array}$ & Evaluation \\
\hline \multirow{2}{*}{1} & I (fabric facing growth medium) & 7 & None & None & \multirow{2}{*}{ Effective } \\
\hline & II & 5 & None & None & \\
\hline \multirow{2}{*}{2} & 1 & 10 & None & None & \multirow{2}{*}{ Effective } \\
\hline & II & 10 & None & None & \\
\hline \multirow{2}{*}{3} & 1 & 10 & None & None & \multirow{2}{*}{ Effective } \\
\hline & II & 10 & None & None & \\
\hline \multirow{2}{*}{4} & I (fabric facing growth medium) & 6 & None & None & \multirow{2}{*}{ Effective } \\
\hline & II & 5 & None & None & \\
\hline \multirow{2}{*}{5} & I (fabric facing growth medium) & 15 & None & None & \multirow{2}{*}{ Effective } \\
\hline & II & 12 & None & None & \\
\hline 6 & I (fabric facing growth medium) & 12 & None & None & Effective \\
\hline
\end{tabular}

Table 9. Results of Candida albicans microbiological tests for the various variants of bioactive insole composites

\begin{tabular}{|c|c|c|c|c|c|}
\hline $\begin{array}{l}\text { Sample } \\
\text { no. }\end{array}$ & $\begin{array}{l}\text { Side of } \\
\text { sample }\end{array}$ & Inhibition zone [mm] & $\begin{array}{l}\text { Growth on agar } \\
\text { under sample }\end{array}$ & $\begin{array}{l}\text { Growth on sample } \\
\text { facing agar }\end{array}$ & Evaluation \\
\hline \multirow[b]{2}{*}{1} & 1 & 11 & None & None & \multirow{2}{*}{ Effective } \\
\hline & II & 9 & None & None & \\
\hline \multirow{2}{*}{2} & 1 & 11 & None & None & \multirow{2}{*}{ Effective } \\
\hline & II & 9 & None & None & \\
\hline \multirow{2}{*}{3} & 1 & 10 & None & None & \multirow{2}{*}{ Effective } \\
\hline & II & 8 & None & None & \\
\hline \multirow{2}{*}{4} & 1 & 10 & None & None & \multirow{2}{*}{ Effective } \\
\hline & II & 7 & None & None & \\
\hline \multirow{2}{*}{5} & 1 & 10 & None & None & \multirow{2}{*}{ Effective } \\
\hline & II & 10 & None & None & \\
\hline 6 & $\mathrm{I}$ & 11 & None & None & Effective \\
\hline
\end{tabular}

indicator of nonwovens stored for $24 \mathrm{~h}$ at a given temperature and air humidity relative to the penetration indicator of freshly produced nonwovens are given in Figures 3, 5, 7, while air flow changes are given in Figures 4, 6, and 8. The results concerning moisture sorption properties under conditions of dynamic air flow are given in Figure 9.

Nonwovens containing SAP introduced into the fibre-forming area during the melt-blown process exhibited an approx. $20 \%$ decrease in the penetration indicator. The simultaneous application of two methods of nonwoven modification improved aerosol filtration effectiveness even more as a result of the concurrent action of several mechanisms: molecular diffusion, particle inertia, direct particle entanglement, gravity, and electrostatic forces, which are in turn affected by nonwoven pore size and the size of particles stopped [4]. The presented results show that fibres made of crystalline polypropylene are highly susceptible to corona-discharge modification.

In most nonwoven variants, the penetration indicator decreased after $24 \mathrm{~h}$ storage both under normal conditions and at high temperature and air humidity. During sample storage under normal conditions, the greatest decrease in the penetration indicator among both charged and uncharged nonwovens was observed for the PP nonwoven containing $5.0 \mathrm{~g}$ of fine SAP (over $40 \%$ and over $25 \%$, respectively). The smallest decrease in the penetration indicator was recorded for the coronacharged nonwoven with $2.5 \mathrm{~g}$ of fine SAP. In terms of air flow resistance, the largest change among uncharged nonwovens was observed for that containing $2.5 \mathrm{~g}$ of coarse SAP, and among charged nonwovens for that containing $5.0 \mathrm{~g}$ of fine SAP. The smallest change in air flow resistance was found for the plain PP nonwoven.

During storage at high temperature and air humidity $\left(\mathrm{T}=30 \pm 2^{\circ} \mathrm{C}\right.$; $\mathrm{RH}=80 \pm 5 \%)$, the penetration indicator decreased most $(25 \%)$ for the uncharged nonwoven containing $2.5 \mathrm{~g}$ of fine SAP, and least $(18 \%)$ for the plain uncharged nonwoven. Among the charged nonwovens, the highest decrease in the penetration indicator (14\%) was recorded for the nonwoven containing 5.0 $\mathrm{g}$ of fine SAP, and the smallest $(3 \%)$ for the nonwoven with $2.5 \mathrm{~g}$ of fine SAP. In the case of both charged and uncharged materials, the highest air flow resistance was found for the nonwoven containing $5.0 \mathrm{~g}$ of fine SAP. In turn, the lowest increase in air flow resistance (8\%) was observed for the charged and uncharged plain nonwovens.

Finally, during storage at high temperature and air humidity $\left(\mathrm{T}=40 \pm 2^{\circ} \mathrm{C} ; \mathrm{RH}=95 \pm 5 \%\right.$ ), the highest decrease in the penetration indicator (more than 25\%) was recorded for the uncharged nonwovens containing $2.5 \mathrm{~g}$ of coarse or fine SAP. On the other hand, the charged nonwoven with $2.5 \mathrm{~g}$ of coarse SAP exhibited an increase in the penetration indicator by $20 \%$. This is due to the fact that coarse polymer particles embedded in the fibres and between them swelled at high temperature and air humidity, leading to a thicker fibre structure and lower 


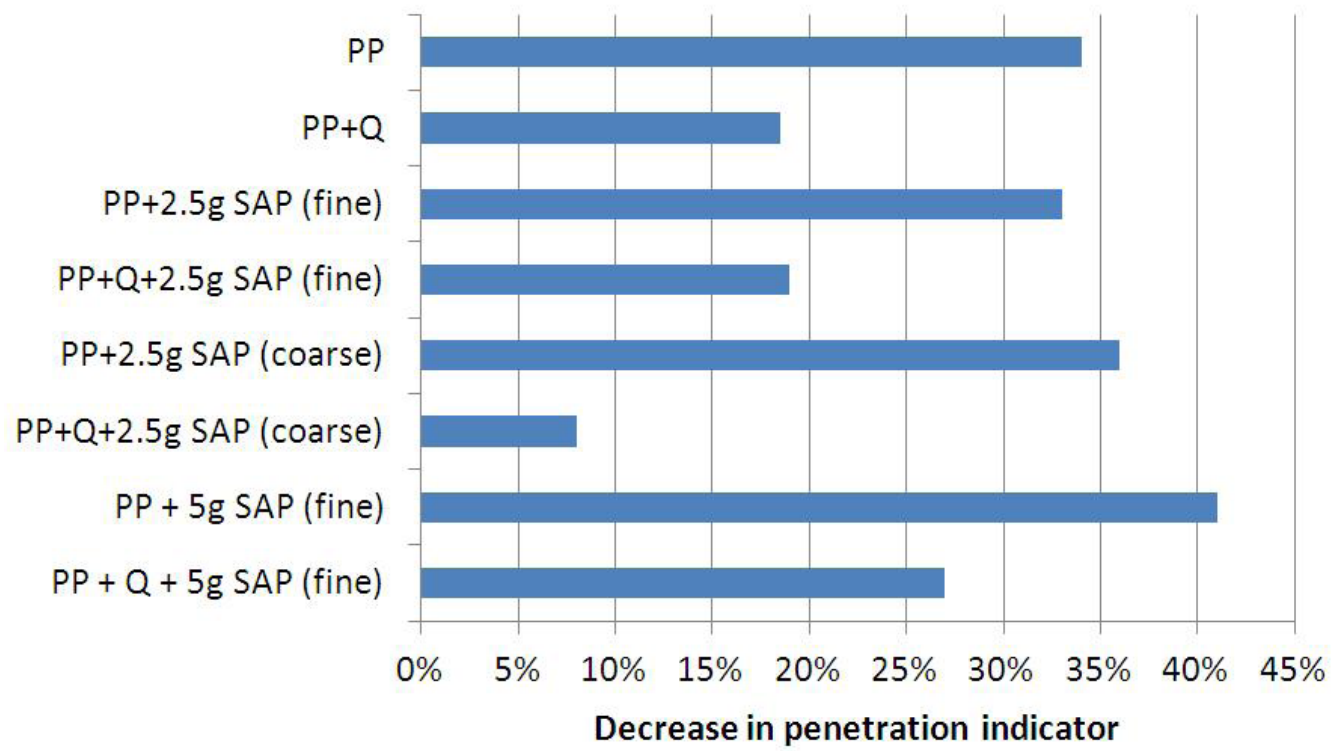

Figure 3. Decrease in the penetration indicator of the developed nonwoven variants following $24 \mathrm{~h}$ storage under normal conditions $\left(\mathrm{T}=20 \pm 2^{\circ} \mathrm{C}\right.$; $\mathrm{RH}=60 \pm 5 \%$ ).

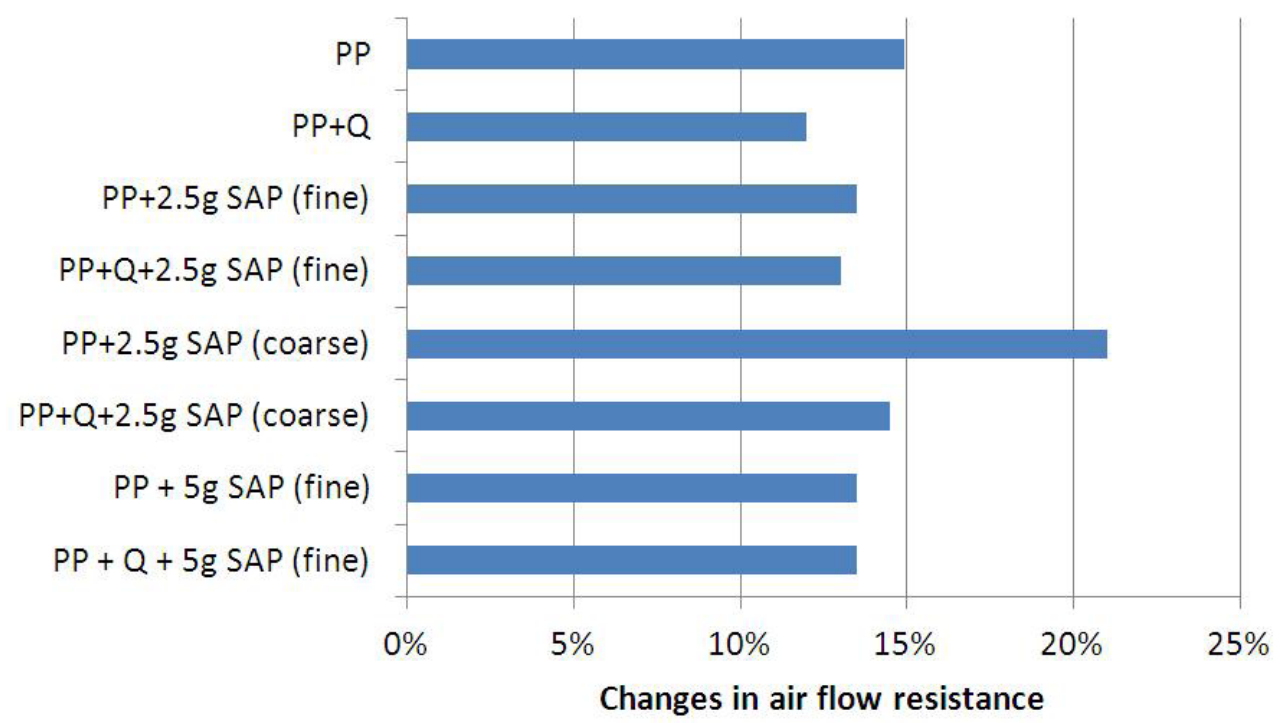

Figure 4. Changes in air flow resistance for the developed nonwoven variants following $24 \mathrm{~h}$ storage under normal conditions $\left(\mathrm{T}=20 \pm 2^{\circ} \mathrm{C}\right.$; $\mathrm{RH}=60 \pm 5 \%)$.

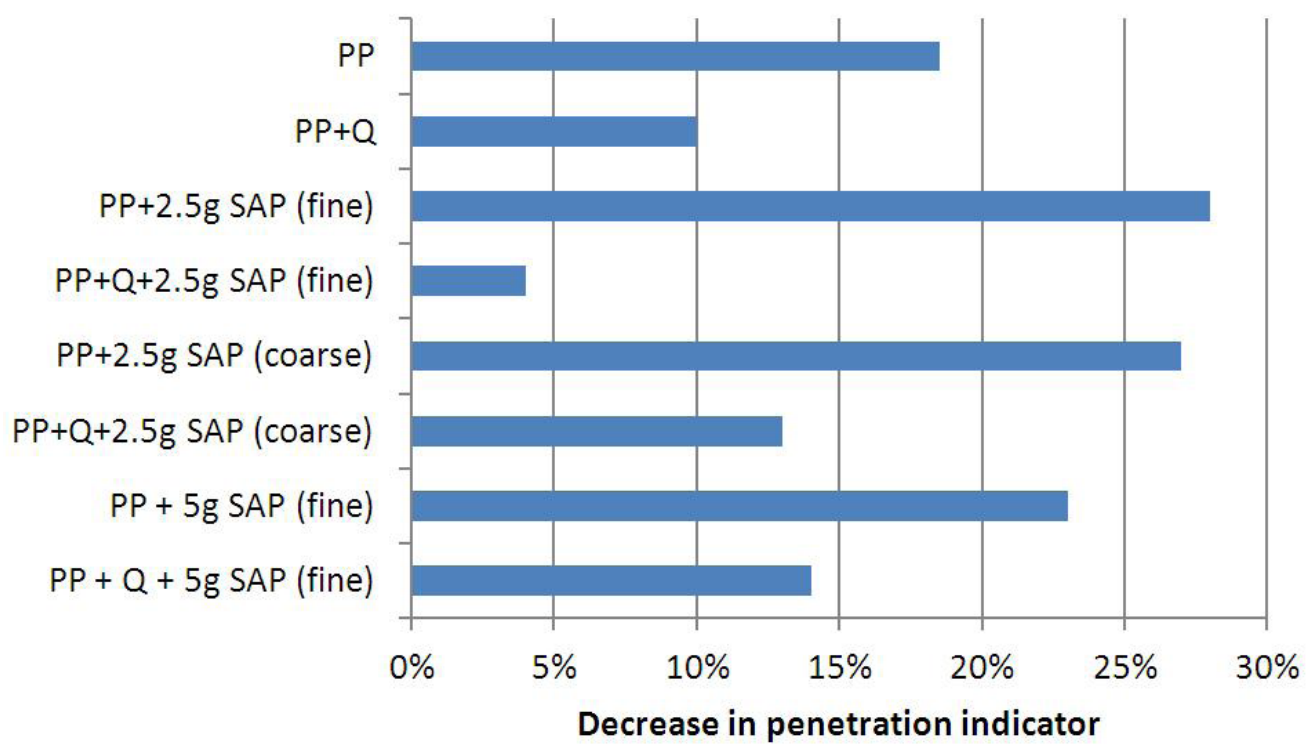

Figure 5. Decrease in the penetration indicator of the developed nonwoven variants following $24 \mathrm{~h}$ storage at high temperature and air humidity $\left(\mathrm{T}=30 \pm 2^{\circ} \mathrm{C} ; \mathrm{RH}=80 \pm 5 \%\right)$. 


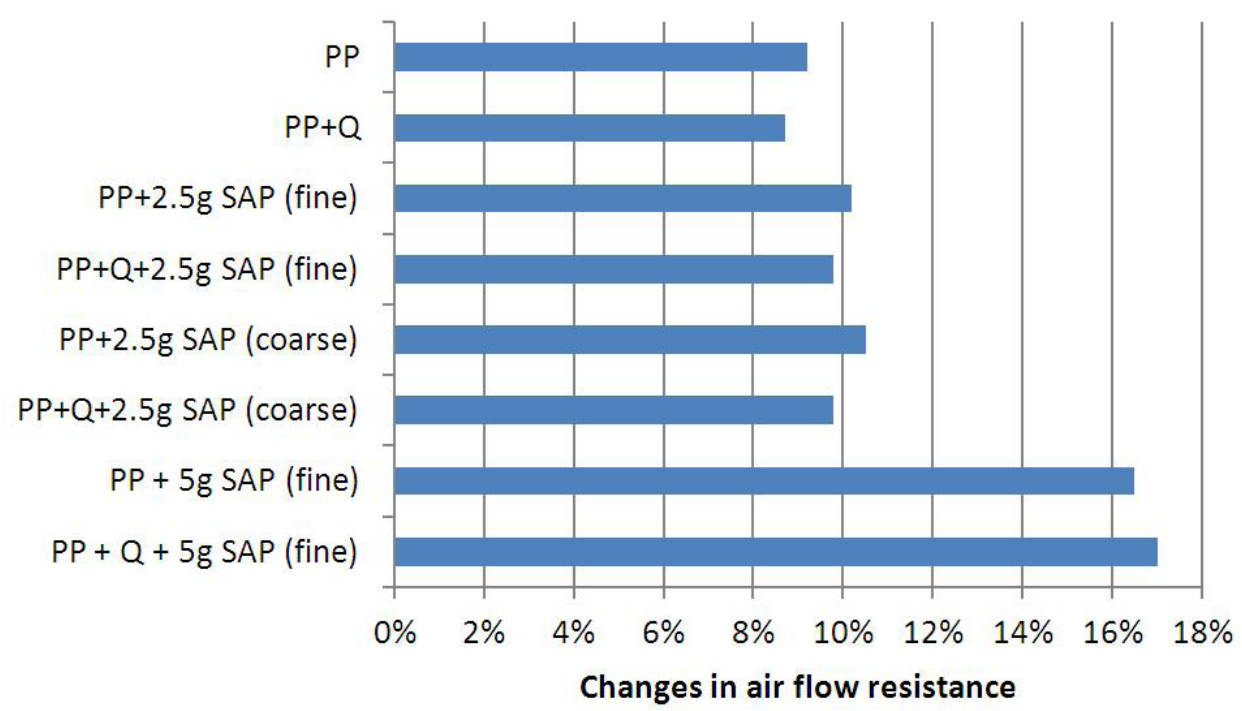

Figure 6. Changes in airflow resistance for the developed nonwoven variants following $24 \mathrm{~h}$ storage at high temperature and air humidity $\left(\mathrm{T}=30 \pm 2^{\circ} \mathrm{C} ; \mathrm{RH}=80 \pm 5 \%\right)$.

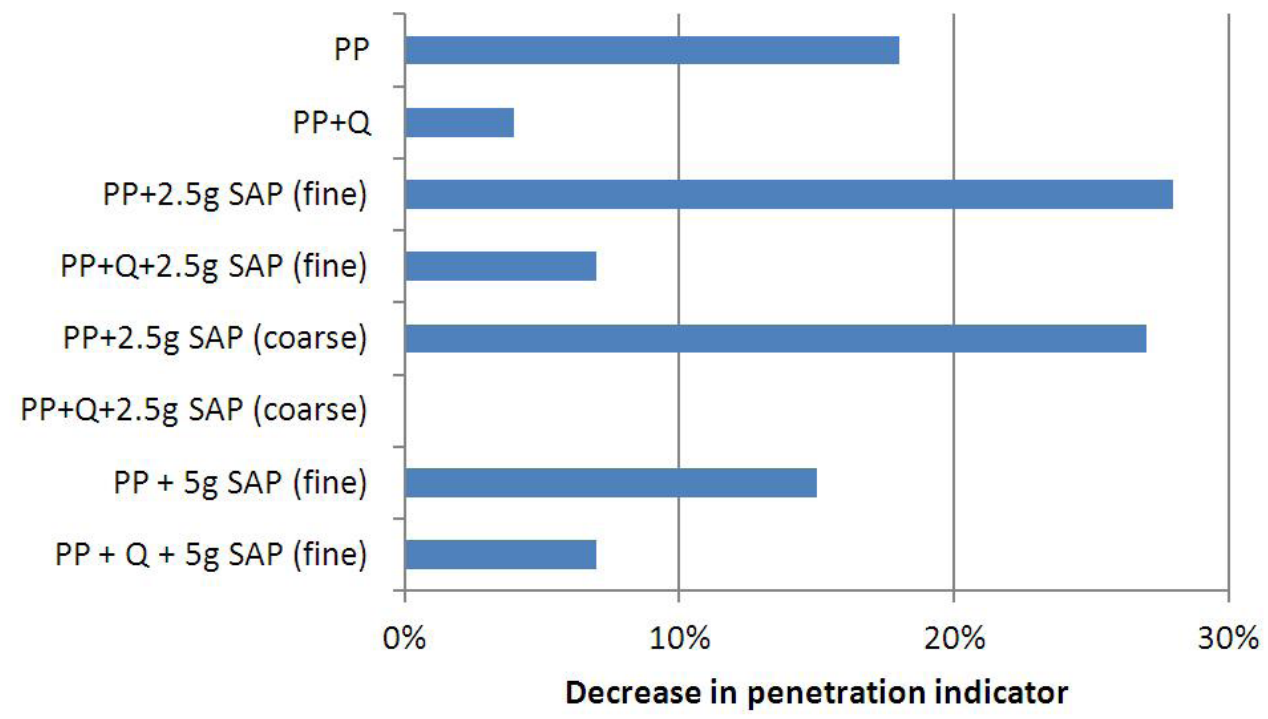

Figure 7. Decrease in the penetration indicator of the developed nonwoven variants following $24 \mathrm{~h}$ storage at high temperature and air humidity ( $\mathrm{T}=40 \pm 2^{\circ} \mathrm{C}$; $\mathrm{RH}=95 \pm 5 \%$ ).

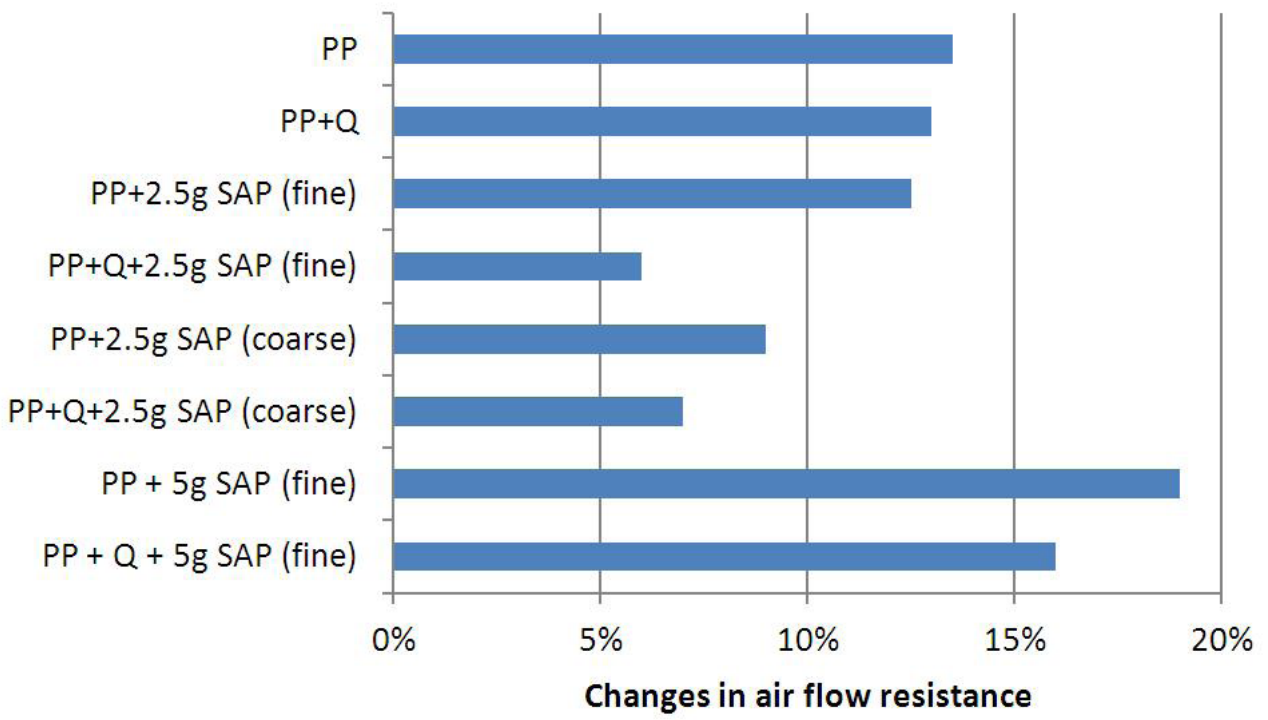

Figure 8. Changes in airflow resistance for the developed nonwoven variants following $24 \mathrm{~h}$ storage at high temperature and air humidity ( $\mathrm{T}=40 \pm 2^{\circ} \mathrm{C}$; $\mathrm{RH}=95 \pm 5 \%$ ). 
filtration efficiency. In the case of air flow resistance, the highest changes were found for the charged and uncharged nonwovens containing $5.0 \mathrm{~g}$ of fine SAP. The lowest increase in resistance (approx. 6\%) was recorded for the charged nonwoven with 2.5 $\mathrm{g}$ of fine SAP.

The improved filtration performance against solid particles ( $\mathrm{NaCl}$ aerosol), as expressed by the penetration indicator, which was observed for the electrostatically activated nonwovens containing SAP is very beneficial for the safety of workers using respiratory protection equipment in environments containing harmful aerosols. Thus, products manufactured from those materials can be used in the workplace for a longer period of time.

The introduction of SAP with a grain size of $250 \mu \mathrm{m}$ into the nonwoven structure led to worse filtration properties as compared to nonwovens not containing that modifier. A smaller grain size (approx. $30 \mu \mathrm{m}$ ) led to an improvement in filtration performance by approx. $75 \%$. In that case, superabsorbent particles became embedded in the fibres as the diameter of the former was similar to that of the latter.

Moisture sorption testing under conditions of dynamic air flow gave the following results:

- The weight of plain PP nonwoven was not found to increase over time.

- In nonwovens containing SAP, a slight decrease in sample weight from 0 to $30 \mathrm{~min}$ was caused by quick evaporation of the condensate that had been formed on the fibres and in the spaces between them. After 30 minutes, the sample weight did not return to the initial weight (prior to testing).
- The weight of the PP nonwoven containing $2.5 \mathrm{~g}$ of coarse SAP increased by $17 \%$ as compared to the plain PP nonwoven.

- The weight of the PP nonwoven containing $2.5 \mathrm{~g}$ of fine SAP increased by $19 \%$ as compared to the plain PP nonwoven and was higher than that of the nonwoven containing coarse SAP. This shows that the grinding of SAP into finer particles did not negatively affect its sorption properties. Indeed, the finer SAP had a more extensive active surface, leading to a slight increase in the weight of absorbed water vapor.

- According to expectations, an increase in the amount of SAP incorporated in the nonwoven (to $5 \mathrm{~g}$ per $0.8 \mathrm{~m}^{2}$ ) led to a $50 \%$ rise in the sorption capacity of the latter as compared to the initial SAP amount.

\section{Conclusions}

The presented methods of melt-blown nonwoven modification by the injection of additives (a bactericidal agent or a superabsorbent) directly into the fibre-forming area and by electrostatic activation may be successfully applied in the manufacture of selected PPE products with a view to improving their functional properties.

The developed method of melt-blown nonwoven modification with a bioactive agent was used to produce materials with good mechanical and sorption properties, which could be incorporated in composite insoles designed for protective footwear. The obtained composite insoles effectively inhibited the growth of microorganisms (Escherichia coli, Staphylococcus aureus, Candida albicans, Aspergillus fumigatus and Trichophyton mentagrophytes) inside

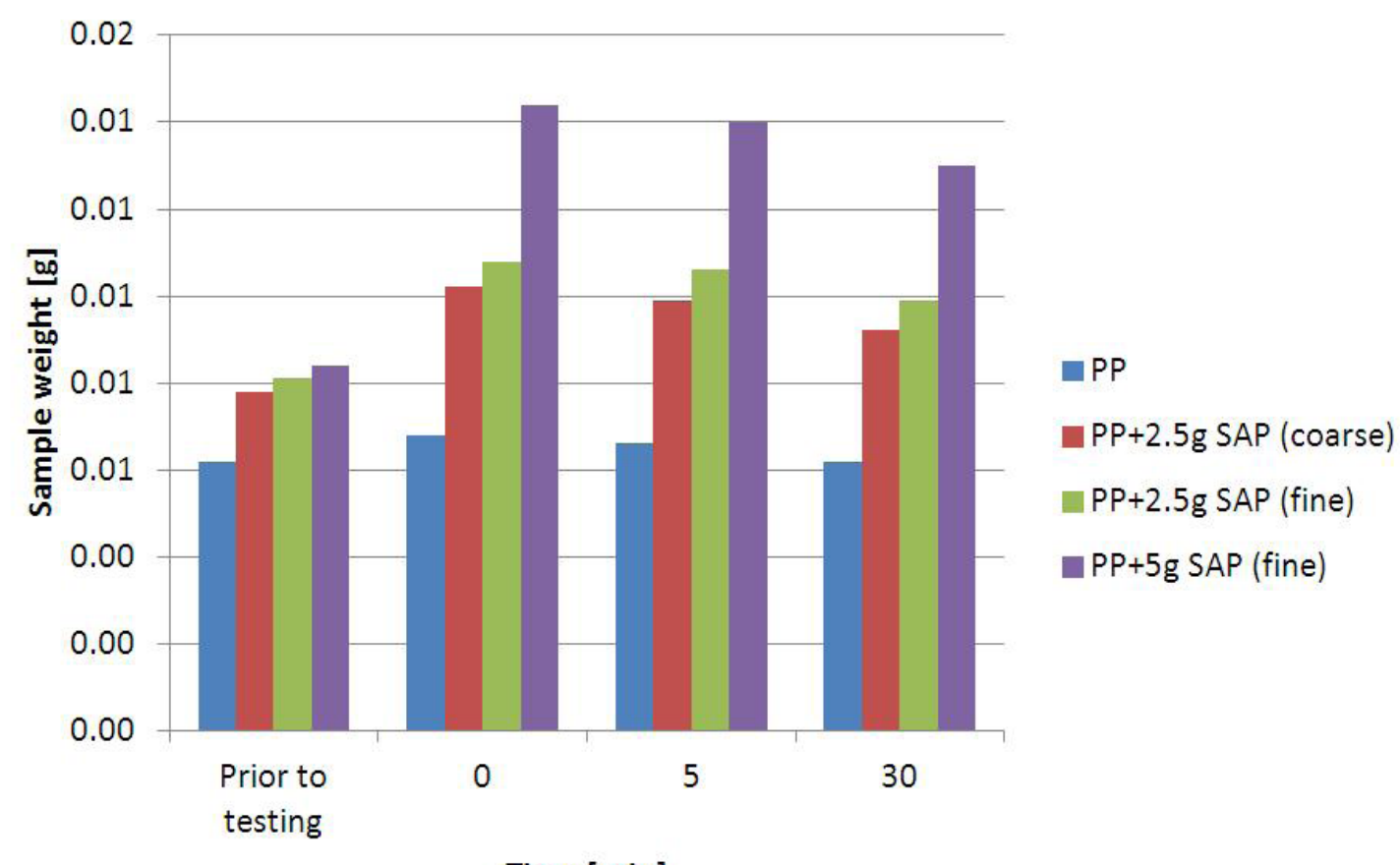

Time [min]

Figure 9. Sample weight as a function of time in a moisture sorption test under conditions of dynamic air flow. 
protective footwear. Among the designed and tested variants of bioactive composite insoles, those containing a bioactive polycarbonate melt-blown nonwoven were found to have superior properties. The high strength of polycarbonate fibres ensured their excellent mechanical characteristics, while their hydrophilicity enabled effective transport of water inside the composite structure, as well as good water vapor permeability.

The developed method of production of electrostatically activated melt-blown nonwovens containing a superabsorbent was used to make a filter material with very good protection properties and high water sorption capacity. This material can be applied in respiratory protective devices, such as airpurifying half-masks.

Among the developed filter nonwovens, the best filtration properties were exhibited by the corona-charged nonwoven containing $2.5 \mathrm{~g}$ of fine SAP per $0.8 \mathrm{~m}^{2}$, which offered low air flow resistance under adverse conditions of work, that is, at high temperature and air humidity $\left(T=40 \pm 2^{\circ} \mathrm{C} ; \mathrm{RH}=95 \pm 5 \%\right)$.

In terms of sorption capacity, the best material was the nonwoven containing $5.0 \mathrm{~g}$ of fine polymer per $0.8 \mathrm{~m}^{2}$ of nonwoven. However, due to the fact that an increased amount of polymer in the nonwoven negatively affected its filtering and functional properties, the optimum amount of superabsorbent was found to be $2.5 \mathrm{~g}$ of SAP per $0.8 \mathrm{~m}^{2}$ of nonwoven.

The presented method of modifier injection into the stream of thermoplastic polymer fibres makes it possible for modifier particles to be partially embedded in elementary fibres without impairing the modifier effect or affecting the fibre structure. In this way, the modifier may be precisely deposited rather than distributed indiscriminately across the structure of the nonwoven.

\section{Editorial note}

\section{Financial Support}

The study was carried out within the framework of Research Grant no. N N404 068240 (contract no. 0682/B/P01/2011/40) financed by the National Science Centre (Poland) in the years 2011-2013 and Phase III of the multiyear program 'Safety and working conditions improvement,' financed in the years 20142016 in the area of research and development by the Ministry of Science and Higher Education and the National Science Centre. The program coordinator is the Central Institute for Labour Protection-National Research Institute (Warsaw, Poland).

\section{Acknowledgements}

The authors wish to thank Michalina Falkiewicz-Dulik, PhD of the Leather Industry Institute, Cracow Branch, for conducting microbiological tests of the insoles.

\section{References}

[1] Brochocka, A., Mian, I., Majchrzycka, K., Sielski, J., \& Tyczkowski, J. (2013) Plasma modified polycarbonate nonwovens as filtering material for liquid aerosols. Fibres and Textiles in Eastern Europe, 22(103), 80-84.

[2] Brochocka, A., \& Majchrzycka, K. (2009). Technology for the Production of Bioactive Melt-blown Filtration Materials Applied to Respiratory Protective Devices. Fibres and Textiles in Eastern Europe, 17(76), 92-98.

[3] Brochocka, A., Majchrzycka, K., \& Domaradzka, S.N (2002). Wpływ warunków aktywacji elektrostatycznej włóknin pneumotermicznych na ich właściwości filtracyjne (Influence of electrostatic activation conditions on the filtration properties of melt-blown nonwovens). Bezpieczeństwo Pracy, 4, 26-28.

[4] Brochocka, A., Majchrzycka, K., \& Makowski, K. (2012). Penetration of different nanoparticles through melt - blown filter media used for respiratory protective devices. Textile Research Journal, 82(18), 1906 - 1919

[5] Chen, G.J., Xiao, H.M., \& Wang, X. (2009). Parameter optimization of corona charging for melt-blown polypropylene electret nonwoven web used as air filter. In ICPADM, Harbin, China, 19-23 July 2009, paper no D-15, pp 389-391, China

[6] Connor, D.J. (1999) Insoles liners and footwear incorporating loofah material. Patent 5930916. USA.

[7] Czaplicki, A. (2006). New method and equipment for manufacturing new adsorptive materials with active carbon content. Fibres and Textiles in Eastern Europe, 4(58), 75-78.

[8] Das, D., Thakur, R., \& Pradhan, A.K. (2012). Optimization of corona discharge process using Box-Behnken design of experiments. Journal of Electrostatics, 70(4), 469-473.

[9] Dean, N. (2011) Shoe insoles with flexible inserts. Patent US20110162234 A1. USA

[10] Deeds, W.E. (1992). Charging apparatus for meltblown webs. Patent US5122048 (A). USA.

[11] Dutkiewicz, J. (2002). Superabsorbent materials from shellfish waste - A review. Journal of Biomedical Material Research, 63(3), 245-381.

[12] EN 13274-3:2001. Respiratory protective devices Methods of test - Determination of breathing resistance

[13] EN 13274-7:2008. Respiratory protective devices methods of test - part 7: determination of particle filter penetration

[14] EN 1392:2007. Adhesives For Leather And Footwear Materials-solvent-based And Dispersion Adhesives-testing Of Bond Strength Under Specified Conditions

[15] EN 14119:2005. Testing of textiles - Evaluation of the action of microfungi

[16] EN 149:2001+A1:2009. Respiratory protective devices. Filtering half masks to protect against particles. Requirements, testing, marking

[17] Falkiewicz-Dulik, M., \& Macura, A.B. (2006). Higiena obuwia w profilaktyce grzybicy stóp (Footwear hygiene in foot mycosis prophylaxis). Mikologia Lekarska, 13(4), 265271

[18] Gulbiniene, A., Jankauskaite, V., \& Kondratas, A. (2011). Investigation of the Water Vapour Transfer Properties of Textile Laminates for Footwear Linings. Fibres and Textiles in Eastern Europe, 19(86), 78-81 
[19] Irzmańska, E. (2014). Footwear use at workplace and recommendations for the improvement of its functionality and hygiene. AUTEX Research Journal, 14(2), 89-94

[20] Irzmańska, E., Brochocka, A., \& Majchrzycka, K. (2012). Textile composite materials with bioactive melt-blown nonwovens for protective footwear. Fibres and Textiles in Eastern Europe, 20(95), 119-125.

[21] Irzmańska, E., Dutkiewicz, J., \& Irzmański, R. (2014). New approach to assessing comfort of use of protective footwear with a textile liner and its impact on foot physiology. Textile Research Journal, 84(7), 728-738

[22] Irzmańska, E., Orlikowski, W., Brochocka, A., \& Majchrzycka, K. (2013) Composite insole for nonpermeable footwear. Patent application P.406296. Poland

[23]ISO 20345:2007. Personal protective equipment Protective footwear

[24] ISO 20645:2006. Textile fabrics - Determination of antibacterial activity - Agar diffusion plate test

[25] ISO 5084:1999. Textiles - Determination of thickness of textiles]

[26] Kałużka, J., \& Kudzin, M. (2011). Włóknina kompozytowa do filtracji powietrza, o właściwościach przeciwdrobnoustrojowych. Patent application P 393698, Poland

[27] Krucińska, I., Strzembosz, W., Majchrzycka, K., Brochocka, A., \& Sulak, K. (2012). Biodegradable particle filtering half masks for respiratory protection. Fibres and Textiles in Eastern Europe, 6B(96), 77-83

[28] Kubik, D.A., \& Davis, D.I. (1980). Melt-blown fibrous electrets. Patent US4215682 (A). USA.

[29] Kuklane $K$. (2004). The use of footwear insulation values measured on a thermal foot model. International Journal of Occupational Safety and Ergonomics, 10(1), 79-86.

[30] Lim, L.T., Auras, R., \& Rubino M. (2008). Processing technologies for poly(lactic acids). Progress in Polymer Science, 33(8), $820-852$.

[31] Motyl, E., \& Łowkis, B. (2006). Effect of air humidity on charge decay and lifetime of PP electret nonwovens. Fibres and Textiles in Eastern Europe, 14(5), 39-42.
[32] Nifuku, M., Zhou, Y., Kisiel, A., Kobayashi, T., \& Katoh, H. (2001). Charging characteristics for electret filter materials. Journal of Electrostatics, 51-52, 200-205

[33] Orlikowski, W., Brochocka, A., \& Majchrzycka, K. (2013). Głowica do wytwarzania modyfikowanych elektretowych włóknin pneumotermicznych (Spinning head for the production of modified electret melt-blown nonwovens). Patent application P.406216. Poland

[34]PN-EN 31092:1998. Textiles- determination of physiological properties, measurement of thermal and water-vapour resistance under steady-state conditions (sweating quarded-hotplate test)

[35] Togahashi, R., \& Ando, K. (1991). Melting a polymer, spinning fibers and putting in a binder and charging. Patent US5051159 (A). Japan]

[36] Tsai, P.P., Schreuder-Gibson, H., \& Gibson, P. (2002). Different electrostatic methods for making electret filters. Journal of Electrostatics, 54(3-4), 333-341.

[37] Twarowska-Schmidt, K. (2004). Evaluation of the suitability of some biodegradable polymers for the forming of fibres. Fibres and Textiles in Eastern Europe, 12(46), 15 - 18.

[38] Urbaniak - Domagała, W., Wrzosek, H., Szymanowski, H., Majchrzycka, K., \& Brochocka, A. (2010). Plasma modification of filter nonwovens used for the protection of respiratory tracts. Fibres and Textiles in Eastern Europe, 83 (6), 94-99

[39] Wadsworth, L.C., \& Hersh, S.P. (1983). Method of making fibrous electrets. Patent US4375718 (A).USA

[40] Wcisło, P., Kałużka, J., \& Pęczkowska, B. (2006). Biodegradable polymers in melt-blown technology. Przegląd Włókienniczy, 1, 28-30.

[41] Yang, Z.Z,, Linm J.H., Tsai, I.S., \& Kuo, T.Y. (2002). Particle filtration with electret of nonwoven polypropylene fabric. Textile Research Journal, 72(12), 1099-1104.

[42] Żenkiewicz, M., Rytlewski, P., \& Malinowski, R. (2011). Metody i urządzenia stosowane w modyfikowaniu tworzyw polimerowych plazma niskotemperaturową (Methods and equipment used in polymer modification with lowtemperature plasma). Polimery-W, 56(3), 185-195. 